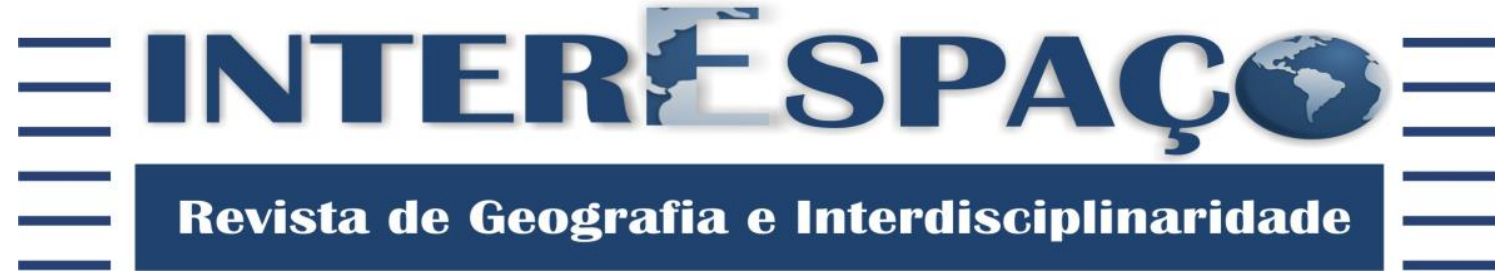

\section{A CRIANÇA E A CIDADE: \\ Percepções e rememorações infantis sobre Pelotas (RS)}

\section{Karla Nazareth Simões de Almeida Tissot}

Mestranda em Memória Social e Patrimônio Cultural pela Universidade Federal de Pelotas (PPGMP/UFPel-RS). Bacharel em Comunicação Social pela Universidade da Amazônia (UNAMA-PA).

karlanazarethtissot@gmail.com

\section{RESUMO}

Esse artigo pretende abordar a percepção da cidade através do ponto de vista de duas crianças, o que lhes chama atenção na paisagem e como expressam o que enxergam, sentem, experimentam no espaço. No entanto, a metodologia inicial - observação participante e entrevista livre em campo - encontrou um obstáculo quando as crianças passaram a silenciar-se acerca da experiência. Desta maneira, uma nova estratégia foi traçada: aplicar técnicas de história oral temática juntamente com a navegação no Google Maps Street View (GMSV), ou seja, procuraram-se os lugares citados no mapa on-line para descobrir, a partir do diálogo lembrança-mapa, quais caminhos e lembranças eram evidenciados. Nessa nova configuração, como considerações parciais, destaco os novos desafios que foram traçados: como fazer entrevistas com crianças tão novas utilizando a história oral? De que forma a utilização do mapa seria útil? E de que maneira a criança pode ser um protagonista no processo de construção da imagem da cidade?

Palavras-chave: Cidade; Infância; Percepção; Memória.

THE CHILD AND THE CITY:

Children's perceptions and recollections of Pelotas (RS)

\section{ABSTRACT}

This paper intends to address on the perception of the city through the perspective of two children, what catches their attention on the landscape and how they express what they see, feel and experience in that space. However, the initial methodology participant observation and free interviews during fieldwork - found an obstacle when the children began to become silent throughout the experiment. Thus, a new strategy was drawn: to apply thematic Oral History techniques with Google Maps Street View (GMSV) navigation, i.e. we looked for the places mentioned in the online map to find out, from the memory-map dialog, what pathways and memories were highlighted. In this new configuration, the highlights are the new challenges that were traced, as partial considerations: how to conduct interviews with such young children using the oral history method? How could the use of the maps be useful? And how can the children be players in the city image building process?

Keywords: City; Childhood; Perception; Memory.

EL NIÑO Y LA CIUDAD:

Percepciones y rememoraciones infantiles sobre Pelotas (RS) 


\begin{abstract}
RESUMEN
Este artículo pretende abordar la percepción de la ciudad desde el punto de vista de dos niños, aquello que les llama la atención del paisaje y como expresan aquello que ven, sienten y experimentan en el espacio. Sin embargo, la metodología inicial observación participante y entrevista libre en campo - encontró un obstáculo cuando los niños pasaron a guardar silencio sobre la experiencia. Por ello, una nueva estrategia fue trazada: aplicar técnicas de historia oral temática junto a la navegación en Google Maps Street View (GMSV). Es decir, buscaron los lugares citados en el mapa on-line para descubrir, a partir del diálogo recuerdo-mapa, que caminos y recuerdos se pusieron de manifiesto. En esta nueva configuración, como consideraciones parciales, destaco los nuevos desafíos que fueron trazados: ¿Cómo realizar entrevistas con niños tan jóvenes utilizando la historia oral? ¿De qué forma la utilización del mapa sería útil? $¿ Y$ de qué manera el niño puede ser un protagonista en el proceso de construcción de la imagen de la ciudad?
\end{abstract}

Palabras clave: Ciudad; Infancia; Percepción; Memoria.

\title{
INTRODUÇÃO
}

Quando Kevin Lynch e Alvin K. Lukashok levantaram a hipótese de que "a memória adulta no presente refletiria verdadeiras preocupações da infância"1 (LUKASHOK; LYNCH, 1956, p. 142, tradução nossa), no trabalho sobre recordações a respeito da paisagem urbana, não pude deixar de pensar no meu projeto de mestrado que trata da relação entre lembranças sobre a infância na cidade de Pelotas durante a década de 1980, a percepção dos lugares significativos nos dias de hoje e as consequentes perspectivas para o futuro da cidade quando as duas imagens, a do passado e a do presente, são confrontadas.

No entanto, minha experiência como mãe de duas crianças, uma de cinco anos, Maria, e outra de três, João ${ }^{2}$, com quem costumo desfrutar o espaço da cidade, me fez atinar para algumas questões não relacionadas diretamente à minha pesquisa de mestrado — mas inspiradas por ela, uma vez que lidarei com a percepção da infância vivida em outro tempo: o que crianças pequenas sentem, percebem e concebem (TUAN, 1980) acerca dos lugares que mais frequentam na cidade? $\mathrm{E}$ mais adiante, quando as entrevistas livres durante a pesquisa de campo não mais pareciam trazer qualquer retorno, essas crianças seriam capazes de lembrarem-se dos lugares e também de narrar as histórias ali vividas?

Para dar início à investigação, o caminho metodológico foi elaborado ainda durante a rotina de lazer familiar, quando passei a somar ao papel afetivo da mãe, o papel da pesquisadora observadora. Na primeira fase, a estrutura da observação para coleta das percepções das crianças foi baseada no método etnográfico que consiste na tríade olhar,

\footnotetext{
1 "Present adult memories reflect actual childhood preoccupations".

2 Para proteger a identidade das crianças, pseudônimos foram utilizados.
} 
ouvir e escrever (OLIVEIRA, 2000), devidamente disciplinados conforme meu referencial teórico, pautado na geografia humanista, com ênfase nos trabalhos de Kevin Lynch (1982) e Yi-Fu Tuan (1980; 1983).

Quanto ao olhar e ao ouvir, essas ações se complementam numa etapa qualificada como "estando lá", o momento em que eu, enquanto pesquisadora, vivo a situação em campo através da observação participante. Nesse caso, porém, existe uma inversão de papéis: uma vez que minha parte enquanto mãe já é bem aceito entre as crianças observadas, eu precisaria então que elas aceitassem também a minha função como pesquisadora interessada em uma relação dialógica entre iguais onde, como interlocutores (e não como mãe/filho, e nem como entrevistadora/entrevistado), tentaríamos trocar informações sobre os lugares visitados em via de mão dupla (OLIVEIRA, 2000), ainda que o foco seja a percepção das crianças e não a minha sobre a paisagem. Durante todas as ocasiões, era negociado um momento para o diálogo e, quando possível, eram feitas anotações sobre o ambiente e sobre como as crianças se comportavam, o que lhes chamava a atenção e o que comentavam espontaneamente ou através das minhas indagações. A observação ocorria desde casa, quando definidos os lugares para o passeio, prosseguindo durante o percurso de carro ou a pé até os lugares.

Por serem crianças muito novas, entendi como mandatório o diálogo durante os passeios para que a percepção das mesmas sobre o ambiente fosse imediatamente anotada e não se perdesse entre as brincadeiras e distrações. Contudo, em pouco tempo, as crianças não mais pareciam dispostas a interagir, sendo preciso elaborar uma estratégia diferente para apreender o que elas absorviam dos lugares. Apenas quando a ação se tornava passado, quando as crianças ficavam longos períodos sem frequentar os lugares, é que partia delas a vontade de recordá-los, narrando o que haviam feito nos espaços, planejando o que poderiam fazer no futuro e, no caso de João, pedindo para ver fotos dos lugares no computador - o que era feito utilizando-se ferramentas de busca na web.

Assim, a partir das condições criadas pelas próprias crianças foi elaborada a segunda fase da pesquisa, que se aproximaria das técnicas utilizadas na história oral temática, no qual, com a aceitação delas, nossas conversas sobre seus lugares favoritos na cidade eram gravadas enquanto navegávamos pelo Google Maps Street View (GMSV), ou de forma aleatória, ou através de suas indicações, ou baseando-me pelos lugares já frequentados e comentados por elas em outras ocasiões. Somente após essas entrevistas que a etapa conhecida como "estar aqui", referente à escrita do observado, do registrado em fotos (ao todo foram anotados vinte e nove pontos que vão desde prédios em ruínas e vegetações, 
até considerações sobre o calçamento e prédios históricos), e do gravado (no caso das entrevistas realizadas após as visitas) passou a fazer parte do "plano do discurso", ou seja, se converteu neste artigo.

\section{PRIMEIRA FASE: OBSERVAR A PERCEPÇÃO DAS CRIANÇAS}

Durante os anos de 1960 e 1970, uma nova abordagem passou a ser desenhada na Geografia. Denominada como Geografia Humanista, contrapunha-se à lógica positivista de espaço ao apoiar-se na fenomenologia para a compreensão do mundo, ou seja, valorizando a visão do indivíduo, dos seus sentimentos, valores, atitudes, experiências e sua percepção em relação ao meio ambiente (ROCHA, 2007).

Especificamente sobre a percepção, esta seria a interação do sujeito com o mundo exterior através dos sentidos (visão, audição, tato, paladar e olfato) combinada com os mecanismos cognitivos que envolvem tanto as características individuais (inteligência, motivações, humor, expectativas), quanto as construídas socialmente, culturalmente (ROCHA, 2007). Ou nas palavras de Yi-Fu Tuan:

[Percepção] é tanto a resposta dos sentidos aos estímulos externos, como a atividade proposital, na qual certos fenômenos são claramente registrados, enquanto outros retrocedem para a sombra ou são bloqueados. Muito do que percebemos tem valor para nós, para a sobrevivência biológica, e para propiciar algumas satisfações que estão enraizadas na cultura (TUAN, 1980, p. 04).

O olhar dos geógrafos humanistas se lança, então, para a subjetividade dos indivíduos e para o entendimento de que cada pessoa possui uma visão, uma percepção única do meio em que se insere. Portanto, quando bem compreendidas as "inter-relações entre o homem e o meio-ambiente (seja esse referente às paisagens naturais ou construídas) a partir de suas expectativas, julgamentos e condutas" (ROCHA, 2007, p. 24), é possível aumentar a qualidade de vida e, consequentemente, a satisfação do indivíduo com o meio onde está inserido.

Nesse contexto, os trabalhos de dois autores me serviram de parâmetro para a observação das crianças durante os passeios: o capítulo "Espaço, Lugar e a Criança", de YiFu Tuan (1983), geógrafo considerado um dos fundadores da Geografia Humanista e cujas reflexões abraçaram o mundo do homem - e também da criança - e a sua relação com a natureza; e o livro "A Imagem da Cidade", de Kevin Lynch (1982), onde é apresentada uma metodologia que pensa o ambiente urbano a partir da percepção das pessoas e de como elas organizam as informações que o espaço lhes transmite (LYNCH, 1982). Assim, 
para melhor aclarar o que foi analisado sobre a percepção das crianças a respeito dos lugares onde elas interagiam, nos tópicos a seguir, procuro fazer uma breve revisão dos textos acima mencionados.

No livro Espaço e Lugar, de 1977, Yi-Fu Tuan (1983) direciona sua atenção para o "espaço" e para o "lugar" a partir da experiência humana. Em um dos primeiros capítulos, inclusive, ele foca na relação da criança com essas categorias e oferece alguns entendimentos de como crianças, em distintos estágios de desenvolvimento, reagem e percebem o ambiente ao redor, ou seja, relevante orientação para entender as capacidades e limitações pelas quais passam a menina e o menino observados e entrevistados para este artigo.

Na referida obra, Tuan (1983) inicia tratando do vínculo cultural que a criança possui desde o seu nascimento, além dos “imperativos biológicos" e das curvas de aprendizagem e compreensão que podem ir além desse fator cultural. A maneira como uma criança percebe o seu meio, em primeiro lugar, está pautada nas limitações e possibilidades dos seus equipamentos biológicos.

Durante as primeiras semanas de vida, por exemplo, o recém-nascido é incapaz de distinguir o seu eu do mundo externo — o mundo não é dualista. Além disso, seus limitados movimentos, aliados ao fato de não possuir firmeza no pescoço, ou por seus olhos não conseguirem focar adequadamente, fazem com que um bebê de pouca idade tenha limitada noção de orientação, permanência e de distinção entre o horizontal e o vertical. Restrições essas que podem se estender até mais ou menos o seu quarto mês de vida.

Nessa primeira fase, a criança explora o meio com a boca, o que lhe é gratificante e possibilita a utilização, além do paladar, dos sentidos de tato e olfato. Durante esse estágio, o bebê se torna consciente de estados de desconforto, associado ao estômago "vazio", e de satisfação, associado ao estômago "cheio", respondendo-os com choro ou sorriso. E, em função de sua visão ainda não estar plenamente desenvolvida, o tato passa a ser o sentido mais utilizado para o reconhecimento de objetos próximos:

O mundo visual da criança é especialmente difícil de descrever porque somos tentados a atribuir-lhe as categorias bem conhecidas do mundo visual do adulto. A maior parte das vezes nos escapa como os sentidos do olfato, paladar e tato estruturam o meio ambiente; até mesmo as pessoas cultas não têm um vocabulário diversificado para descrever os mundos olfativo e tátil (TUAN, 1983, p. 25).

Tão logo aprende a andar, a criança, entre um ano e meio a dois anos, quer explorar o ambiente da mãe. Suas investidas raramente se distanciam dela e, quando muito, não mais do que alguns segundos. Essa exploração do mundo também inclui tatear as proximidades: pegar folhas, grama, sujeiras, rastejar e trepar em obstáculos. Durante esse período, o distante e o 
próximo atraem o interesse da criança, dificilmente o que está no meio. O mundo é articulado em categorias polarizadas, classificado em contrastes fortes, separando pessoas entre "familiares" e "estranhos", discriminando brinquedos entre favoritos e pouco favoritos, e por volta dos dois/dois anos e meio, entendendo opostos espaciais, como "cima" e "embaixo", “aqui e ali", "longe e perto”, “topo e fundo", "frente e atrás”, “casa e exterior”.

Em média, uma criança entre três e cinco anos é plenamente capaz de não se perder em um trajeto curto conhecido, mas não saberia explicar como o fez, já que os conhecimentos conceituais das relações espaciais não são dominados por crianças dessa faixa etária. Na maioria dos casos, a criança apenas recorda do ponto de partida e de chegada, sem a descrição de detalhes, ou da lógica do caminho e dos passos que devem ser tomados até o ponto desejado. As crianças pequenas, como observa Tuan (1983), se preocupam mais com as coisas em si do que com as suas exatas relações espaciais.

Entre cinco e seis anos, crianças podem facilmente compreender paisagens vistas de cima, ainda que seja um ângulo fora dos limites da sua experiência, mas familiar se considerarmos que elas conhecem o mundo em miniatura através dos seus brinquedos, além das imagens vistas através de fotografias em revistas, pelas imagens na televisão e, hoje em dia, também pela internet. Como orienta o autor, para uma criança, a compreensão de uma imagem vista de cima é mais provável do que uma cena oblíqua, inclinada.

A mãe é o primeiro lugar da criança, é seu ambiente, um refúgio que representa estabilidade e permanência. Com o tempo esse apego é transferido para objetos e localidades, sendo o lugar, geralmente, um tipo grande e imóvel de objeto ambivalente: ora onde se deseja estar (porque proporciona prazer, conforto); ora, não (porque o prazer e o conforto podem dar lugar à insegurança, ao medo). Logo quando possível a criança dá nome as coisas que passam a ser, por serem classificáveis, mais "reais":

As coisas não são bem reais até que tenham nomes e possam ser classificadas de alguma maneira. A curiosidade pelos lugares faz parte de urna curiosidade geral sobre as coisas, surge da necessidade de qualificar as experiências; adquirem assim um maior grau de permanência e se ajustam a algum esquema conceitual (TUAN, 1983, p. 33).

À medida que a criança cresce, a noção de lugar se torna mais sofisticada. Entre três e quatro anos, ela passa a se comunicar mais precisamente sobre sua localização, tem seu interesse por lugares distantes, bem como uma relativa consciência dessa distância. Ao perguntar para uma criança onde ela mora, por exemplo, ela pode responder não apenas que mora em uma casa, mas também mencionar detalhes como o nome da rua ou da cidade. Uma criança nessa faixa etária, no entanto, não foca muito sua atenção em um 
ambiente como um todo, mas em detalhes e, principalmente, em pessoas. A imaginação da criança a respeito dos lugares está presa à atividade, ao presente, diferente da do adulto, que é envolta em significados que vão sendo acumulados ao longo do tempo, fazendo com que crianças pequenas e imaginativas olhem "prosaicamente para os lugares que aos adultos lhes trazem tantas recordações” (TUAN, 1983, p. 38).

Procurar entender a maneira própria de a criança experimentar o meio em que está inserida, ou seja, de como o seu "imperativo biológico do crescimento" influencia o que pode ser compreendido por ela, independentemente da cultura que a acolhe (TUAN, 1983, p. 20), é essencial para que não se interprete suas ações e interesses como similares aos dos adultos que as observam. Para uma criança, mostrar-se interessada em observar uma paisagem, por exemplo, não implica que ela esteja a avaliar sua dimensão ou beleza, mas que talvez, dependendo da idade, só esteja procurando a mãe ou algum lugar instigante e seguro para brincar.

\section{Algumas notas sobre A imagem da Cidade}

Em 1960, o urbanista Kevin Lynch escreveu o livro A Imagem da Cidade, que veio a se tornar uma das mais relevantes obras para a Geografia Humanística. Segundo Lynch (1982), dois conceitos importantes são trabalhados: o da legibilidade (legibility), que consiste na "facilidade com a qual as partes (da cidade) podem ser reconhecidas e organizadas numa estrutura coerente" (LYNCH, 1982, p. 13), favorecendo, assim, a sensação de orientação, segurança e uma melhor experiência urbana; e o da imaginabilidade (imageablity), compreendida como a:

[...] qualidade de um objeto físico que lhe dá uma grande probabilidade de evocar uma imagem forte num dado observador. É essa forma, cor, disposição, que facilita a produção de imagens mentais vivamente identificadas, poderosamente estruturadas e altamente úteis (LYNCH, 1982, p. 20).

Esses dois conceitos se relacionam, uma vez que "imagens fortes" facilitariam a legibilidade e a leitura da cidade tornando-a "bem formada, distinta, notável; como que convidaria os olhos e os ouvidos a uma maior atenção e participação" (LYNCH, 1982, p. 20). Além disso, o autor observou que as pessoas utilizam pelo menos cinco elementos para estruturar a sua imagem da cidade que, ainda que não sejam fixos e que variem conforme o entorno, o contexto e as características individuais do observador, uma vez identificados e utilizados com frequência, ajudam a criar familiaridade e identidade com o espaço e, por conseguinte, ajudam a fortalecer um sentido de lugar. São eles: 
Caminhos ou vias (paths): podem ser ruas, calçadas, linhas de trânsito, canais, fortes elementos estruturadores da cidade, dos outros elementos, da experiência como um todo, por onde as pessoas se deslocam. A imagem da cidade é prejudicada quando os principais caminhos não apresentam uma forte identidade. Por outro lado, podem se tornar bastante relevantes quando concentram um tipo especial de uso ou de atividades (rua associada ao comércio, à boemia, por exemplo); quando possuem características espaciais muito marcantes (larga, estreita) ou por determinados tipos de fachadas de prédio, pela existência significativa de vegetação, e por apresentarem continuidade, assim como início e fim bem definidos.

Limites (edges): são interrupções na continuidade, fronteiras entre duas partes, barreiras, cortes, "costuras", limites muitas das vezes impenetráveis. Podem ser rios, estradas, viadutos, praças e calçadas para pedestres. O excesso de limites prejudica a visão da cidade como um todo e serão percebidos mais como barreiras do que como elementos organizadores de ligação.

Bairros (districts): médias ou grandes regiões urbanas percebidas como relativamente homogêneas, com traços em comum que permitem com que seja diferenciado do resto da cidade. Os bairros podem ser identificados em seu interior, uma vez que o observador pode adentrá-lo, ou pelo seu exterior. De uma forma ou de outra, as "continuidades temáticas" que diferenciam os bairros podem se referir a detalhes, texturas, símbolos, tipos de edificações, atividades, usos, habitantes, topografia, grau de conservação. Também podem ser considerados bairros "introvertidos" ou "extrovertidos".

Cruzamentos ou pontos nodais (nodes): são estratégicos, podem ser junções, locais de interrupção num transporte, um cruzamento, momentos de mudanças de uma estrutura para outra, esquinas. Podem ser concentrações temáticas, seja pelos hábitos ali presentes ou pelo seu caráter físico, além da possibilidade de serem considerados "centros" em um bairro pelo seu caráter de núcleo polarizador.

Elementos marcantes ou marcos (landmarks): são externos ao observador, normalmente representado por um objeto físico de larga escala como um edifício, uma árvore ou montanha. Sua principal característica é a sua distinção e evidência no contexto em que está inserido. Alguns pontos marcantes situam-se em grande distância, desempenhando a função de direção, tais como torres e cúpulas. E para as pessoas mais habituadas a cidade, podem ser marcos menores, mais próximos, como fachadas de lojas e puxadores de portas, preferencialmente por estabelecerem um contraste com elementos próximos. 
Isto posto, a observação e as perguntas direcionadas às crianças eram orientadas a identificar se algum(ns) desse(s) elemento(s) era(m) aludido(s), isto é, se possuíam destaque na percepção das crianças e se, a partir disso, eram utilizados para que as mesmas organizassem a sua imagem da cidade.

\section{O meio ambiente percebido por Maria e João}

Conforme mencionado anteriormente, vinte e nove pontos foram demarcados (Figura 1) e organizados nas seguintes categorias: ambiente construído e ambiente natural, externo e/ou interno - facilmente observados uma vez que, desde muito pequenas, as crianças conseguiriam diferenciar o que é domínio da natureza como algo "natural" em contraste com um domínio artificial, man-made, construído (SEBBA, 1991).

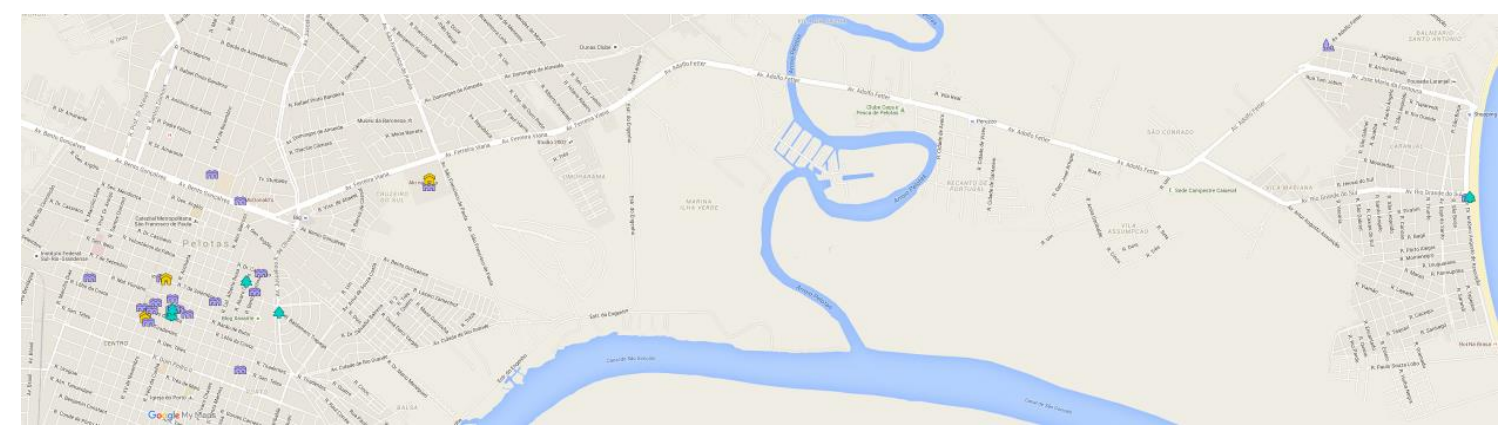

Figura 1 - Pontos observados demarcados no mapa on-line

Fonte: Google Maps. Disponível em: <

Para efeito de resultado dessa primeira fase serão evidenciados alguns elementos por categoria, priorizando as interações iniciais, quando as crianças ainda demonstravam animação e interesse em participar das conversas.

\section{Ambiente natural (externo)}

Foram considerados todos os lugares de acesso público, não cercado, em que a paisagem natural tenha possuído protagonismo para as crianças. Como paisagem natural, lendo-se - a partir da percepção delas - os espaços que possuíam grama, árvores, terra/areia, água (praia, lago, canal), em que o concreto/cimento não fosse o principal

3 Prinstscreen feito em março de 2016. 
elemento identificado. Primeiramente, trato da Praça Palestina (Figura 2), localizada entre as ruas Doutor Cassiano, Voluntários da Pátria, Bento Martins e Álvaro Chaves ${ }^{4}$.

Um vasto espaço ao ar livre que só pode ser desfrutado quando a grama está aparada e o terreno não está alagadiço devido às chuvas. Apesar de possuir a denominação de praça, o ambiente não se parece com as praças que as crianças costumam frequentar. Assim, em nenhum momento eles identificaram o espaço como tal e sim como um campinho em que podem empinar pipa e correr, um lugar onde "a grama é boa, a gente cai e não se machuca" (MARIA, 2015, informação verbal).

Em 2015, foi cogitada a construção do prédio da Câmara Municipal de Pelotas na praça em questão e, após uma tarde de brincadeiras naquela área, perguntei o que eles achavam de empreender ali alguma construção, uma vez que era um espaço sem nada, vazio, de acordo com a percepção de alguns moradores da vizinhança ouvidos durante a audiência pública para a apresentação da proposta (CÂMARA MUNICIPAL DE PELOTAS, 2015). No entanto, a percepção da menina era bem diferente:

\footnotetext{
Não, não tem que mudar. Não é vazio. Ali tem plantinhas. Ali nasceram plantinhas. Viu? Caiu uma sementinha no chão, nasceu plantinha, nasceu uma arvorezinha... Ali é legal, dá pra soltar pipa, correr. Não tem que mudar, tem que ficar do jeito que está (MARIA, 2015, informação verbal) 5 .
}

O menino de três anos, no entanto, possuía outra sugestão para o campo que ele considera bobo: “é bobo, não tem brinquedinhos” (JOÃO, 2015, informação verbal) ${ }^{6}$.

Ainda assim, o relato sobre o lugar era rico em descrições e experiências. Apesar de ser um campo aberto, onde só existem gramas, raramente aparadas, e poucas árvores, sem qualquer urbanização para pedestres ou, como bem lembrou uma das crianças, sem equipamentos lúdicos, os relatos tratavam de corridas pelo interior de um túnel de árvores (que para eles, eram muitas) e uma montanha em que podiam subir e observar ao redor. $\mathrm{Na}$ Figura 2, por exemplo, eles estão em cima do que descreviam como montanha.

Para elas, independentemente da existência ou não de brinquedos, o que lhes parece demarcar aquele como um local de brincadeiras (e feito para crianças) é a grande extensão de gramado, as árvores e as imperfeições no terreno que lhes permite estimular os sentidos e a imaginação.

\footnotetext{
${ }^{4}$ Disponível em: < https://goo.gl/maps/mYxsJvgZaKE2>.

${ }^{5}$ Diário de campo, 31/10/2015, por volta das 18h48, observação de Maria, após brincadeira na praça.

${ }^{6}$ Diário de campo, 31/10/2015, por volta das 18h48, observação de João, após brincadeira na praça.
} 


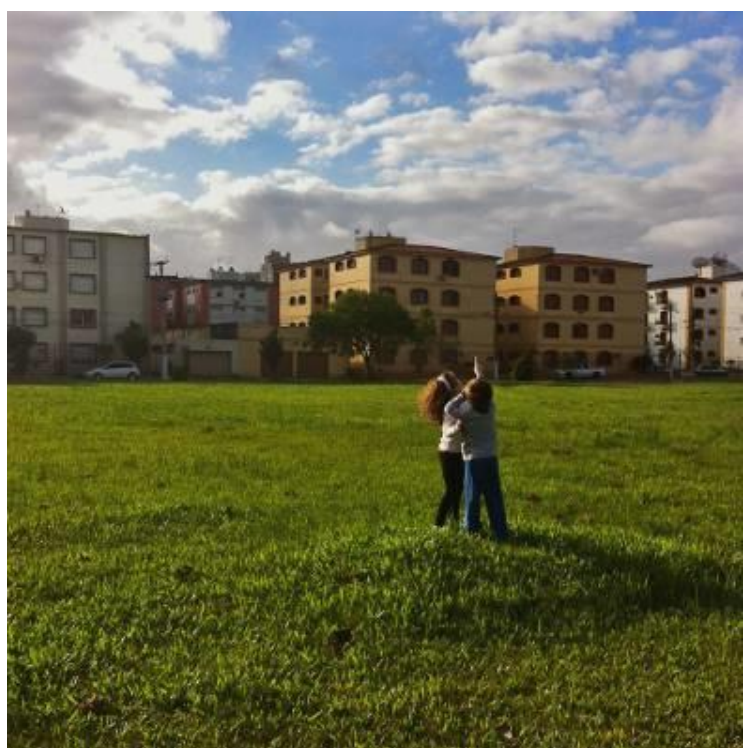

Figura 2 - A montanha do campinho

Fonte: Arquivo pessoal da autora, out. 2015.

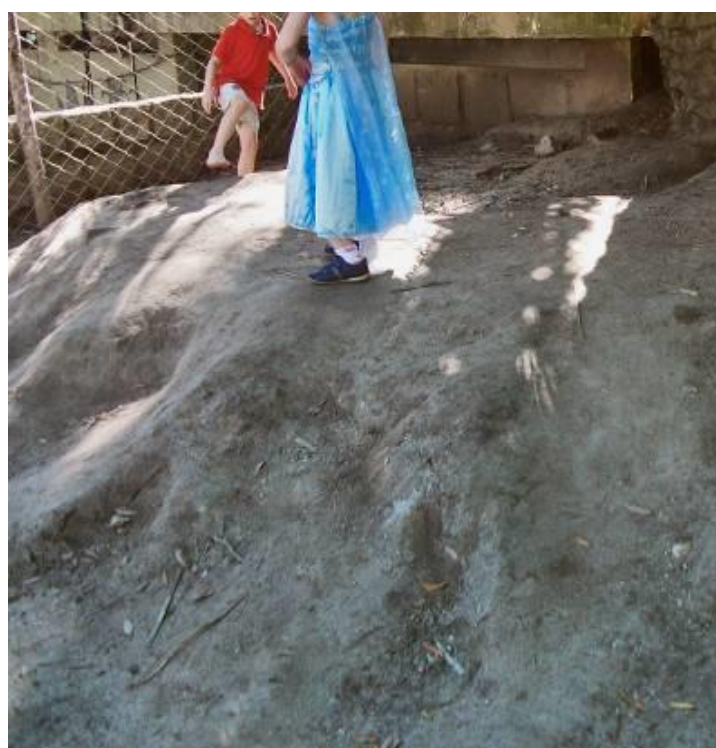

Figura 3 - A montanha da praça

Fonte: Arquivo pessoal da autora, dez. 2015.

Na Praça Coronel Pedro Osório ${ }^{7}$, ao contrário, existe uma área reservada para as crianças (além de urbanização com bancos, passeios, iluminação, chafariz, jardinagem), e periodicamente eles frequentam esse espaço. No entanto, ainda que possam aproveitar os brinquedos do parquinho, eles e outras crianças, repetidas vezes, preferem uma elevação de terra localizada próxima ao banheiro público e a uma árvore que protege a guarita da guarda municipal (Figura 3).

O elevado também foi nomeado como montanha e a praça, por causa dele, é identificada como a praça da montanha. Naquele pequeno metro quadrado de terra, eles passam a maior parte do tempo dedicado à praça, preferindo-o aos brinquedos onde não se sentem seguros. A existência dos equipamentos, aliás, serve mais como um indicativo de que, naquele espaço, as crianças são bem-vindas, seja para explorar o ambiente, seja para utilizar os brinquedos que, apesar do desinteresse por parte de Maria e João, são bastante concorridos nos fins de semana ensolarados. A própria montanha constantemente é alvo de conflito e disputa entre as crianças que querem apropriar-se exclusivamente das brincadeiras ali.

\section{Ambiente construído (externo)}

Nessa categoria entraram todas as construções, intervenções humanas nos espaços públicos (como monumentos, equipamentos urbanos, objetos, veículos percebidos

${ }^{7}$ Disponível em: < https://goo.gl/maps/pi2wWE42WBG2>. 
isoladamente, pavimentação e as fachadas dos prédios). Um dos exemplos escolhidos foi anotado durante o percurso rumo à escola de Maria, realizado algumas vezes a pé. O casarão (Figura 4), situado na Rua Almirante Barroso, esquina com a Rua Sete de Setembro ${ }^{8}$, é um elemento que, devido ao seu estado de avançada deterioração, contrasta imediatamente com os prédios mais modernos ao redor. Ao notar que o casarão lhe atraía o olhar, perguntei sua opinião a respeito do que estava enxergando, respondendo-me que era "feio não cuidarem de um lugar que alguém usou..." (MARIA, 2015, informação verbal) 9 .

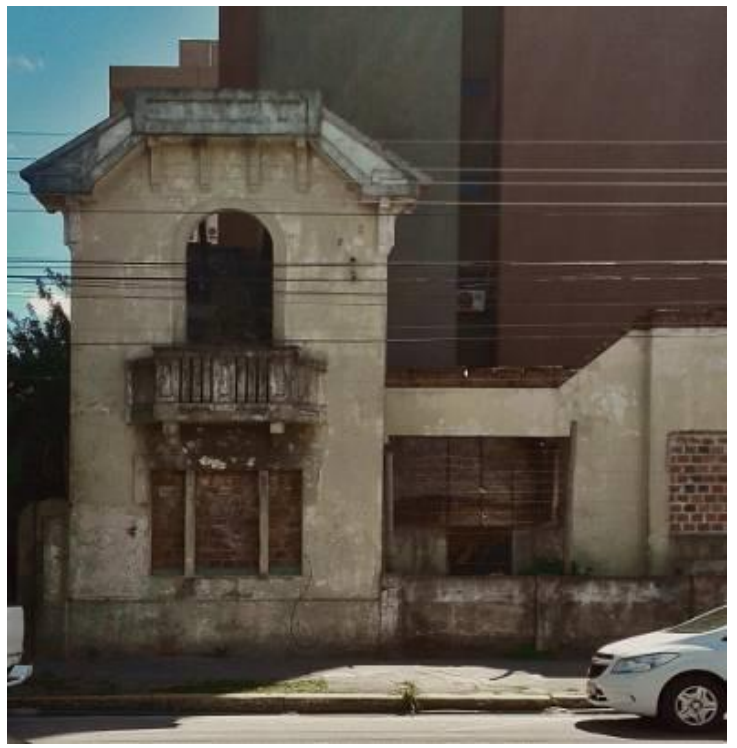

Figura 4 - Casarão em ruínas

Fonte: Arquivo pessoal da autora, set. 2015.

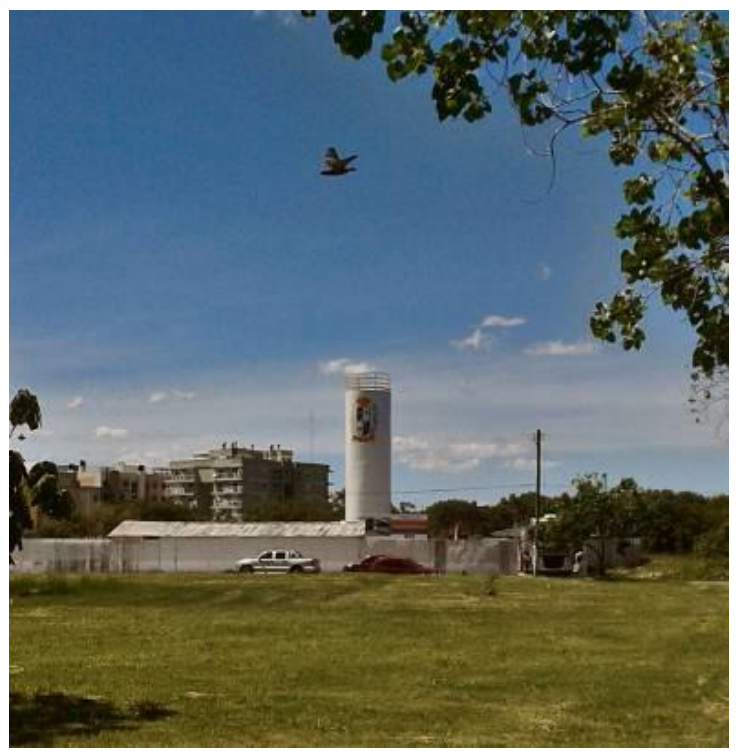

Figura 5 - Caixa d'água

Fonte: Arquivo pessoal da autora, nov. 2015.

A sua resposta simples e direta me fez pensar numa provável profundidade do que ela conseguia perceber na paisagem. O prédio contrastante tornava-se para ela um marco existente em um dos caminhos para a escola (LYNCH, 1982), mas, além disso, ela parecia fazer a leitura do casarão em níveis que iam além dos valores estéticos (novo, velho, feio, bonito). Para ela, o feio era faltarem com a manutenção, afinal, a casa não se cuida sozinha. Além disso, a manutenção deveria ocorrer para além do deixar o entorno mais ou menos agradável, ou mais ou menos seguro, mas porque o casarão trazia em si os usos passados de outras pessoas.

Em se tratando de elementos marcantes, João possui a cidade organizada mentalmente por alguns elementos. São eles: a caixa d'água de um ginásio em construção (Figura 5), a torre do McDonald's (Figura 6), o letreiro do supermercado Big (Figura 7), as luzes brancas do Shopping Pelotas (Figura 8) e a torre (guindaste) do Xavante (Figura 9). A

\footnotetext{
${ }^{8}$ Disponível em: < https://goo.gl/maps/DWtBteRgXmS2>.

${ }^{9}$ Diário de campo, 30/9/2015, por volta das 15h10, resposta de Maria.
} 
caixa d'água ${ }^{10}$, que é chamada de "caixa cheia de água" pelo menino, demarca fortemente a região onde ele mora, a sua vizinhança, ainda que seja uma construção nova - no mapa do GMSV mais atualizado de março de 2015, o terreno ainda era baldio (Figura 10).

Outro marco importante é a torre com a letra "M" do McDonald's (Figura 6), que fica na Avenida Bento Gonçalves ${ }^{11}$. E sobre essa torre é preciso fazer uma observação; aliás, sobre os marcos em geral, mas principalmente os associados a lugares de consumo, onde nessa listagem também incluo o luminoso do supermercado Big ${ }^{12}$ (Figura 7) e as luzes do shopping ${ }^{13}$ (Figura 8). Até o momento, todo elemento que chama a atenção do menino por sua grandiosidade e luminosidade (Maria não reporta comentários animados por objetos dessa natureza), é, em primeiro lugar, associado a um conjunto de emoções que não necessariamente dizem respeito à materialidade das coisas, mas sim, a experiência vivida nesses lugares.

No caso da caixa d'água, nos deparamos com uma exceção, pois como ela surgiu inesperadamente no terreno, a surpresa provocada pela existência do objeto foi o que lhe causou a primeira impressão. No caso dos marcos ligados ao comércio, no entanto, esses só passaram a possuir relevância quando João se tornou consumidor dos lugares, tomandoo por um sentimento de topofilia ${ }^{14}$ devido ao prazer experienciado neles, neste caso, o prazer ligado através dos laços de consumo travados. Em inúmeras ocasiões, João utiliza o verbo "morar" quando expressa a vontade de retornar a esses lugares (durante a história oral, João utiliza o verbo morar para se referir ao shopping, por exemplo).

\footnotetext{
${ }^{10}$ Disponível em: <https://goo.gl/maps/m7jakiappDw $>$.

${ }^{11}$ Disponível em: < https://goo.gl/maps/x5GXE24LdF32>.

12 Disponível em: < https://goo.gl/maps/ojqGWQUJXpK2>.

${ }^{13}$ Disponível em: < https://goo.gl/maps/bNpw6uDXHTm $>$.

14 Termo definido por Tuan (1980) que representaria o elo afetivo entre seres humanos e o meio ambiente material.
} 


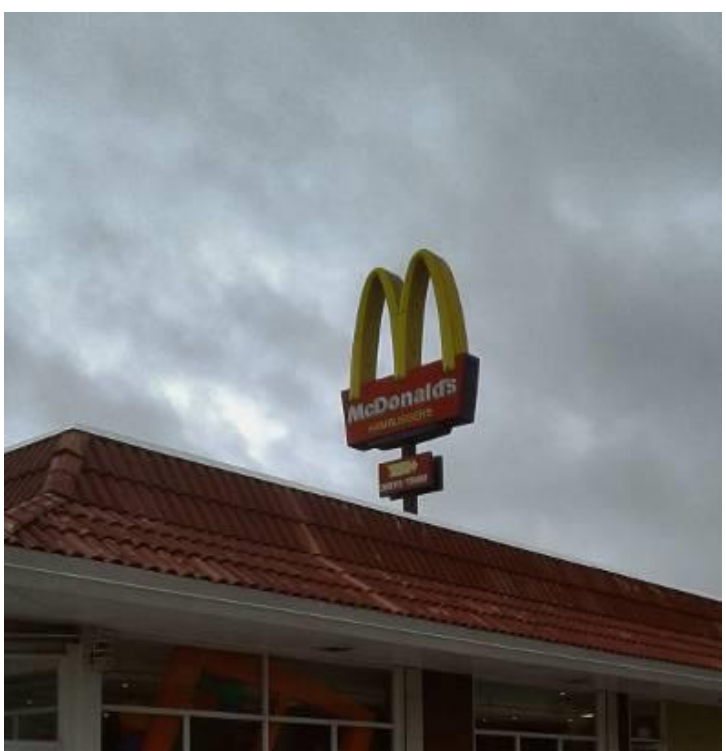

Figura 6 - Torre do McDonald's

Fonte: Arquivo pessoal da autora, dez. 2015.

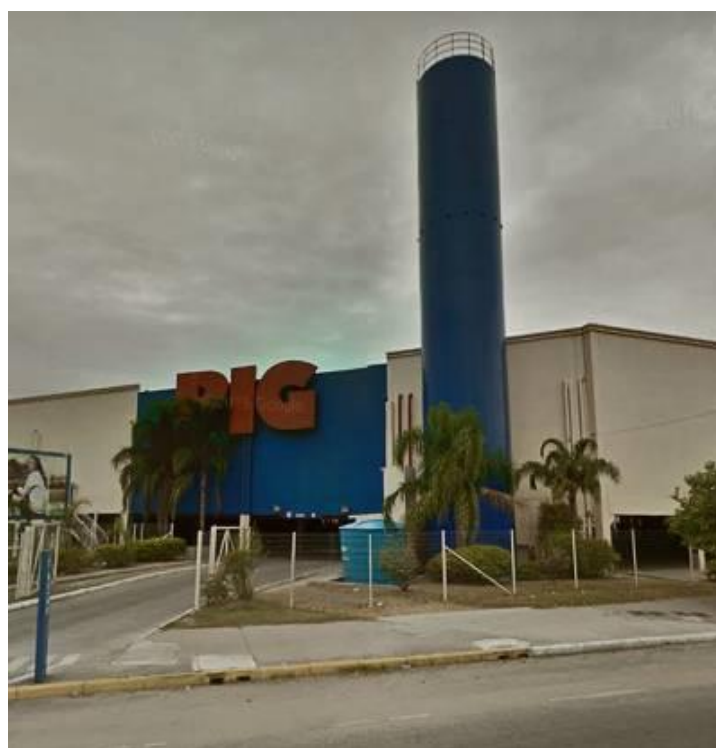

Figura 7 - Letreiro do supermercado Big Fonte: Printscreen GMSV, mar. 2016.

Os elementos, então, além de demarcarem os lugares favoritos, reforçam a permanência dos mesmos - e dos bens de consumo que eles guardam. Permanência (e consequente sensação de estabilidade e segurança) que pode ser conferida mesmo à noite e à distância. Para uma criança de três anos, que recém aprendeu que os objetos permanecem ainda que saiam do seu campo de visão, olhar pela janela do quarto e avistar de longe as luzes do shopping e o letreiro luminoso do supermercado, lhe causa uma sensação de conforto que precisa ser repetida diariamente.

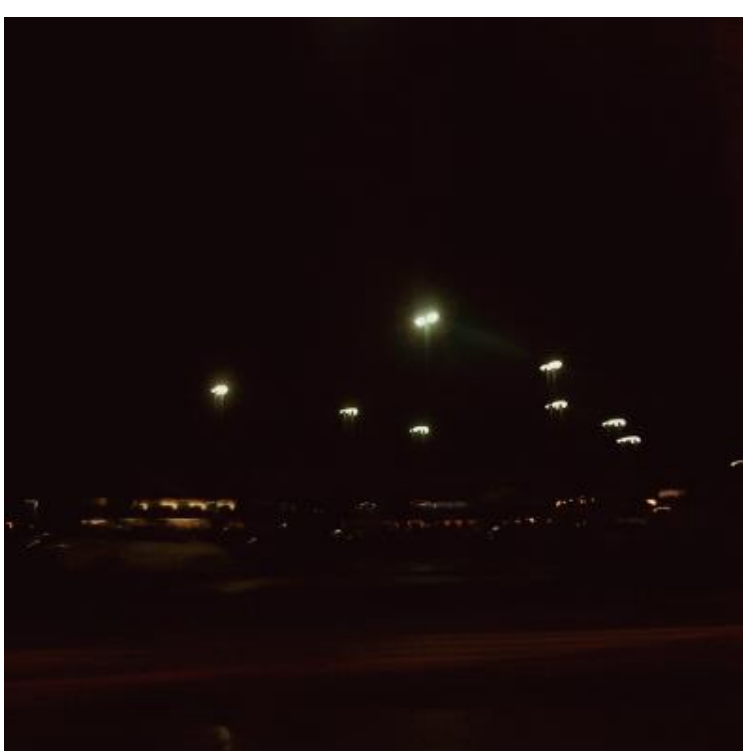

Figura 8 - Luzes brancas do shopping

Fonte: Arquivo pessoal da autora, jan. 2016.

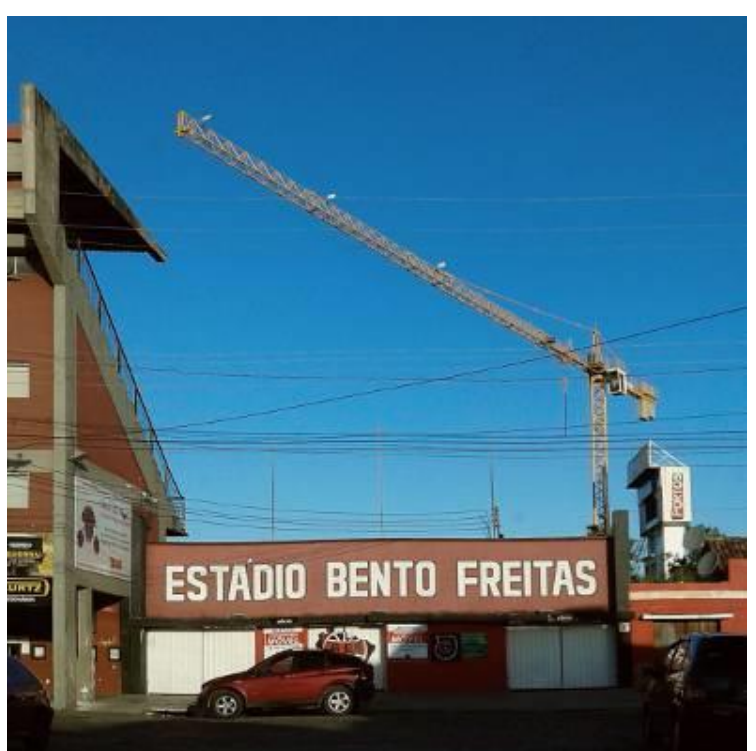

Figura 9 - Torre do Xavante

Fonte: Arquivo pessoal da autora, mar. 2016. 


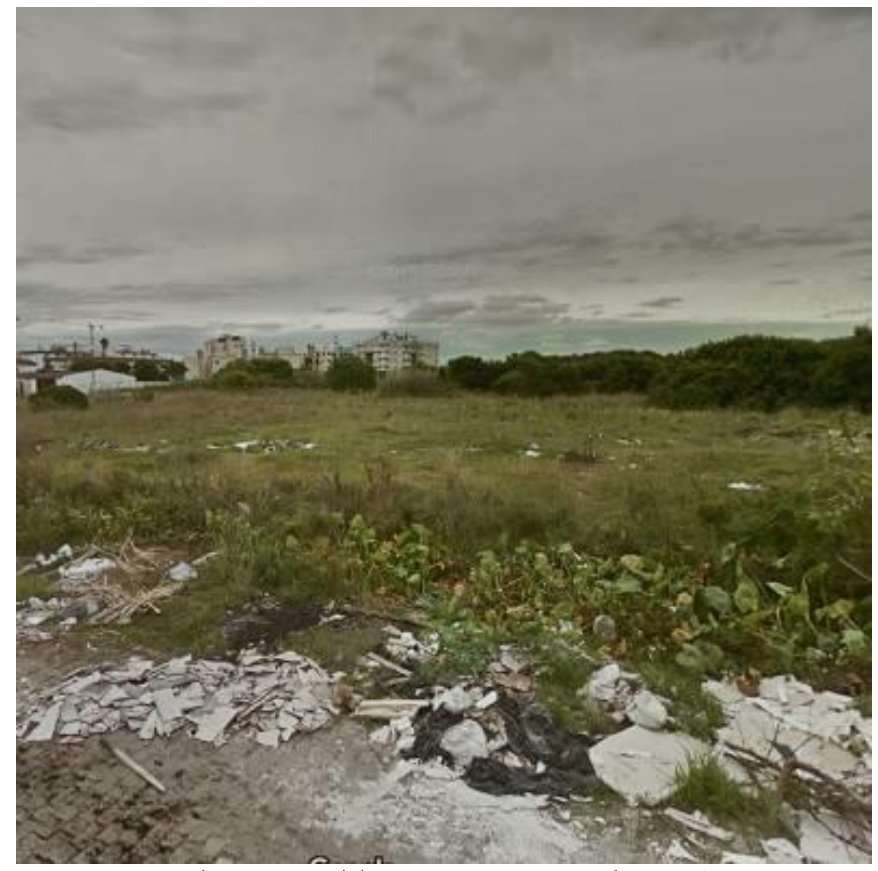

Figura 10 - Terreno em março de 2015

Fonte: Printscreen do GMSV, mar. 2015.

O guindaste no Estádio Bento de Freitas, que João chama de torre do Xavante, (Figura 9) surgiu recentemente e é provisório, porém, para a criança, o objeto ganhou um significado bastante forte, uma vez que tornou possível para ele identificar, através da janela do quarto, em qual direção e posição o estádio se encontra. Assim que chega da escola, a primeira ação do menino é correr para o quarto e verificar, à esquerda, as luzes do shopping e a do supermercado e, à direita, o guindaste. Seguro de que tudo está como havia deixado, ele prossegue com sua rotina infantil.

O apego à torre do Xavante é fruto do carinho pelo time de futebol, e o sentimento surgiu por proximidade geográfica e não por incentivo familiar. O menino que se mudou antes dos dois anos para Pelotas, durante passeios vespertinos com o avô, caminhava com frequência pela frente do estádio, logo começou a associar a diversão acompanhado do avô ao time. Portanto, o estádio (com ou sem sua torre), e, consequentemente, o time, fazem parte da vizinhança onde ele se sente em casa.

\section{Ambiente construído (interno)}

O interior de prédios, casas, construções em geral, públicas ou privadas, fazem parte desse grupo. Para exemplificar, foi escolhida uma das visitas ao Mercado Central de Pelotas ${ }^{15}$, um ponto da cidade que elas reconhecem imediatamente - Maria, pelo prédio como um todo e

${ }^{15}$ Disponível em: <https://goo.gl/maps/hs6r4csD5X82>. 
João, primeiramente pela torre, que normalmente é o tipo de elemento que chama a sua atenção. Como é um prédio que identificam à distância e se mostram sempre muito animados para visitar, perguntei se sabiam o que era ali: “é a casa da formiga!” (JOÃO, 2015, informação verbal), me respondeu o menino; "é a Fenadoce "16" (MARIA, 2015, informação verbal), me respondeu a menina. João também concorda que ali seja a Fenadoce, mas a Fenadoce, para ele, nada mais é do que "a casa da formiga", formiga essa que, para Maria, "está em todos os lugares” (MARIA, 2015, informação verbal), como se andassem (Figura 11).

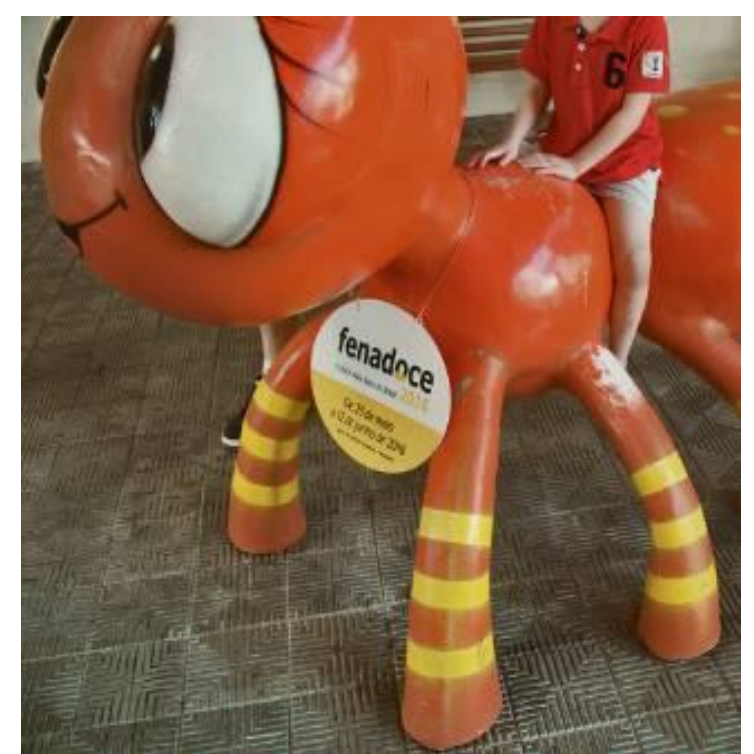

Figura 11 - Formiga do Mercado Central

Fonte: Arquivo pessoal da autora, dez. 2015.

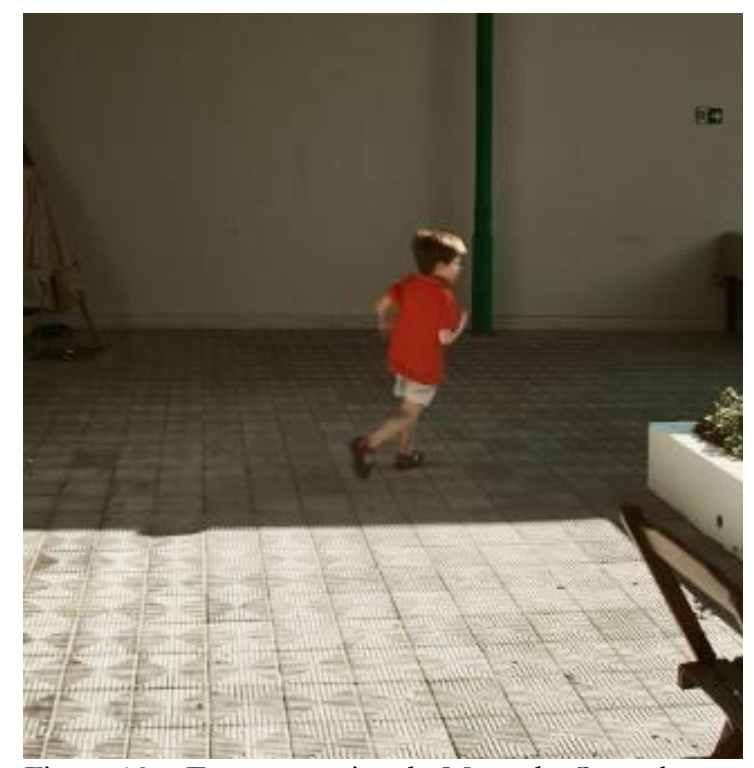

Figura 12 - Espaços vazios do Mercado Central Fonte: Arquivo pessoal da autora, dez. 2015.

Além de perguntar o que era, para eles, o lugar, também indaguei para que o lugar lhes servia: "pra correr" (Figura 12), foi a resposta que os dois me deram. Ali, ao contrário do shopping, eles não reconhecem as lojas, eles não reconhecem o consumo. Para eles, os espaços vazios que existem no interior do mercado, o satisfatório senso de espaço (LUKASHOK; LYNCH, 1956), que lhes comove, depois do ritual de subir na formiga, a "dona da casa", são um convite para que sejam ocupados com suas brincadeiras, uma mensagem de boas-vindas. Apesar disso, para João, a comoção com a torre do Mercado não é tão intensa como a comoção com as demais torres já comentadas.

Próximo dali a relação com o Café Aquários (Figura 13), ao contrário do Mercado, é de consumo. No café ${ }^{17}$ é possível comprar sorvete e chocolate e, por conta dessa relação de consumo e satisfação, - conforme já observado, provoca uma forte ligação com os espaços - o prédio é facilmente lembrado mesmo quando não avistado. Ao perceberem que entraram na

\footnotetext{
${ }^{16}$ A Feira Nacional do Doce, Fenadoce, possui uma formiga como símbolo.

${ }^{17}$ Disponível em: < https://goo.gl/maps/XqvfEMBxPrz>.
} 
rua do café, por exemplo, (e isso também se deve por perceberem o calçamento e os demais prédios que formam a imagem da rua como um todo - Figura 14), imediatamente eles se animam e perguntam se podem ganhar as guloseimas, como de costume.

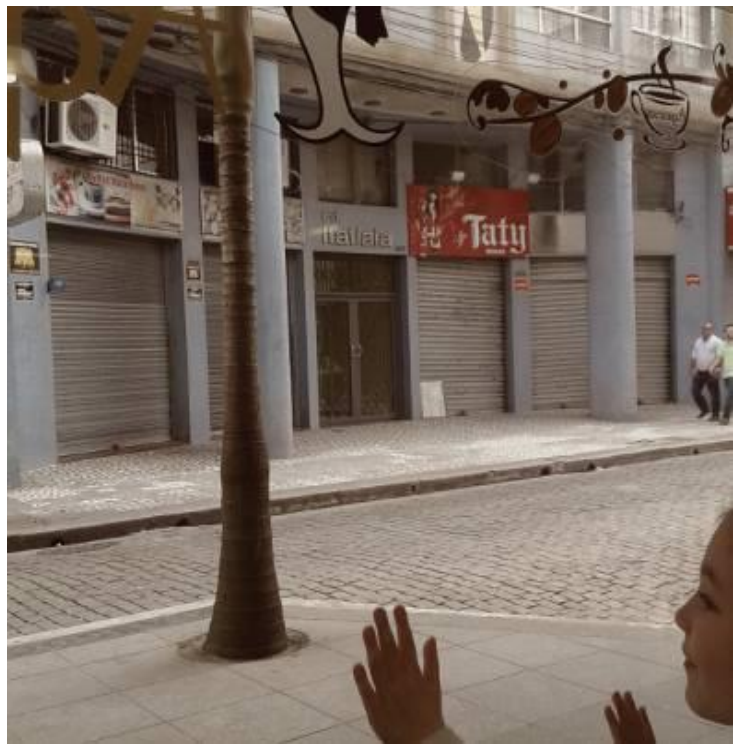

Figura 13 - Café Aquários

Fonte: Arquivo pessoal da autora, dezembro de 2015.

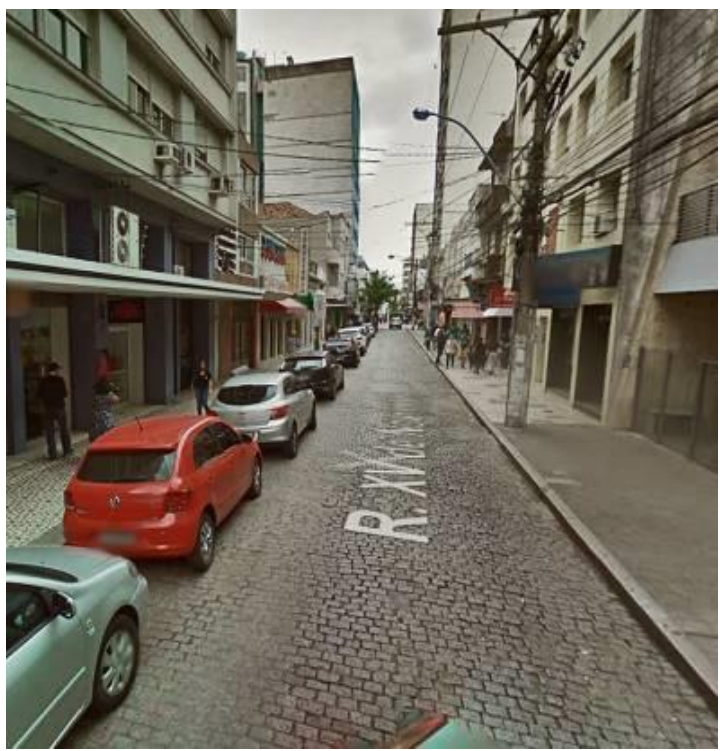

Figura 14 - A imagem da rua

Fonte: Printscreen GMSV, março de 2016.

Uma vez no lugar, os laços são fortalecidos quando realizam o consumo. A fachada não é tão importante quanto o interior do prédio - que é identificado pelos seus produtos.

\section{Ambiente natural (interno)}

A paisagem entendida como natural entre muros, cercas e paredes, públicas ou privadas, entram nesse grupo. Foi durante a pesquisa de campo que usarei como exemplo para essa categoria, em visita à Casa Museu Estância do Laranjal (Figura 15) na Avenida Adolfo Fetter ${ }^{18}$, que a metodologia apresentou os primeiros sinais de desgaste. Aquela havia sido a nossa primeira visita ao local, logo na entrada fomos recepcionados por um enorme portão de pedras e um túnel de árvores. Enquanto o carro adentrava a propriedade, na lateral esquerda era possível avistar um imenso acampado, lagos e cavalos. Até então, toda a paisagem natural lhes causava encantamento e motivação para falar, contudo, após negociarmos o momento para conversas, ao pergunta-lhes sobre suas impressões, Maria apenas respondeu, "legal”, enquanto João se manteve em silêncio.

${ }^{18}$ Disponível em: <https://goo.gl/maps/kEh8ySEknJT2 $>$. 


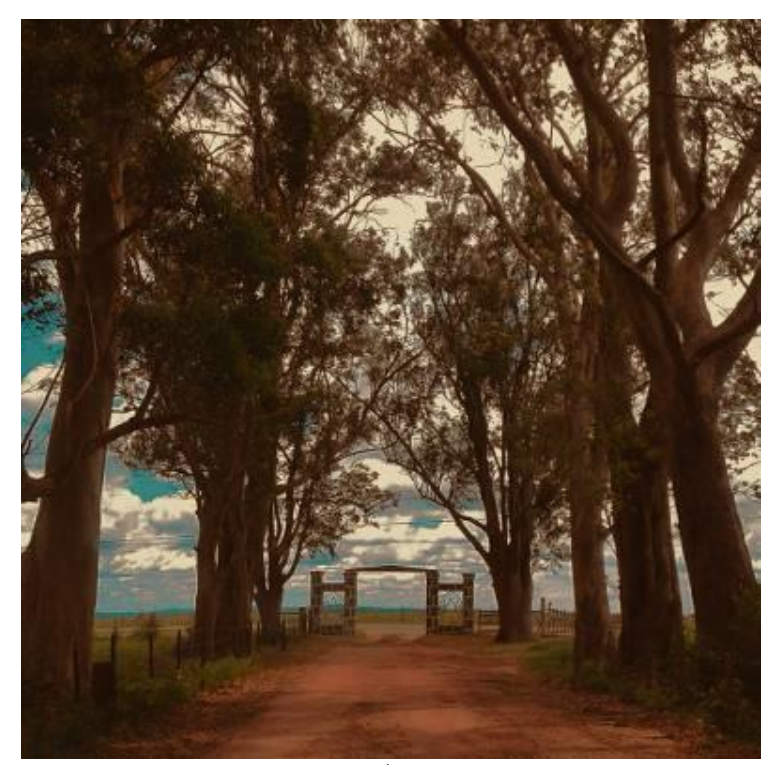

Figura 15 - Estância do Laranjal

Fonte: Arquivo pessoal da autora, nov. 2015.

A resposta seca, sem qualquer empolgação me pareceu ser resultado da combinação das seguintes razões: (1) talvez eu estivesse projetando a minha empolgação a respeito do lugar sobre eles; (2) desânimo/incômodo por ser horário de almoço; (3) o evento que ocorreria naquele espaço havia sido transferido de última hora para outra parte da cidade, logo, não chegamos a descer do carro e tudo o que observamos foi feito através do veículo em movimento; (4) minhas perguntas durante a visita os distraía da experiência em si, gerando irritação, e (5) a metodologia precisava ser reavaliada. No dia seguinte, retornei minha tentativa de entrevistar a menina, mas novamente a resposta permaneceu inalterada.

Quando as entrevistas eram novidade, as crianças demonstravam interesse em participar. Com a repetição da dinâmica, ficou evidente que interromper o momento da interação com o meio não era uma escolha acertada. Uma vez longe da casa materna, os ambientes que lhes eram apresentados, sejam externos, ou internos, naturais ou construídos pela mão humana, passam a ser prioridade para os sentidos, e as crianças focam em tentar perceber cada metro quadrado que os seus olhos e os seus corpos conseguirem alcançam (COLLOT, 1990 apud ROCHA, 2007). Elas querem explorar e manipular o espaço, aprender com os dedos, com os ouvidos, com o olfato, com a própria imaginação quando o conhecimento ainda não thes pode explicar o que percebem (SEBBA, 1991).

Então, a criança anda pela cidade não apenas observando ao redor, mas passando a mão pelas paredes, em muros, interagindo com sujeiras, folhagens, gravetos que encontram pelo chão, tirando os sapatos, pulando em poças de água, subindo em montinhos de terra (LUKASHOK; LYNCH, 1956; TUAN, 1983). É o momento de tocar/ser tocada pela 
A criança e a cidade: percepções e rememorações infantis sobre Pelotas (RS) Karla Nazareth Simões de Almeida Tissot

cidade. De explorar, se afastar dos pais, como observou Tuan (1983) e, através da dinâmica de ir e vir, ampliar o seu mundo que começa restrito, no colo de algum adulto ou na área bem delimitada do parquinho infantil.

Aos poucos, a distância a ser explorada vai ganhando maior dimensão e os contrastes, que são mais facilmente percebidos pelos pequenos — longe e perto, escuro e claro, sem árvores e com árvores, alto e baixo (TUAN, 1983), tornam-se os primeiros elementos que lhes servem como referência de localização (LYNCH, 1982). Os limites entre a terra e a água do pequeno lago, por exemplo, são evitados, pois provocam insegurança. Os limites entre o chão da praça e o asfalto, também. A alta torre do Mercado, vista de longe, é um sinal de que as brincadeiras na praça e no próprio mercado estão próximas. O relevo acidentado que lhes parece uma montanha dá nome e identidade a todo o espaço onde o mesmo surgiu.

Aliás, aquilo que conseguem nomear, classificar, lhes transmite uma sensação de estabilidade e permanência, e também lhes serve como indicador (TUAN, 1983). A montanha da praça, a casa da formiga, o lugar para comer chocolate são reconhecidos e entendidos muitas vezes em conjunto, são seus referenciais no que diz respeito aos lugares para lazer. A torre do Xavante, o campinho, o letreiro do supermercado Big indicam o caminho para o aconchego do lar.

Acrescento que estes são percursos feitos, geralmente, de carro e que, ao contrário dos percursos feitos a pé, sempre lhes parecem distantes. Ainda que não lhes cause esforço se locomoverem de automóvel e que o tempo ao percorrer uma dada distância seja menor indo de carro do que a pé, o fato de conseguirem percorrê-lo a pé é interpretado como próximo enquanto um lugar igualmente distante, mas que só é percorrido de carro, lhes passa a impressão de ser mais distante. O esforço associado à estimativa de distância (TUAN, 1983), para as crianças, parece ser maior em situações de tédio (ficar sentado, parado, sem divertimentos) do que em situações em que se sentem livres para explorar, brincar, correr, descobrir, manusear.

$\mathrm{Na}$ etapa seguinte, quando as crianças são estimuladas a recordarem os passeios enquanto observam a imagens dos lugares disponíveis no mapa on-line, será possível observar como esses elementos aparecem na construção de suas narrativas.

\section{SEGUNDA FASE: UTILIZAÇÃO DO GOOGLE MAPS STREET VIEW (GMSV) COMO SUPORTE À TÉCNICA DE HISTÓRIA ORAL TEMÁTICA COM CRIANÇAS}


É igual a entrevista da pediatra, mas essa é mais legal porque é de lembrar.

(MARIA, 2015, informação verbal) $^{19}$

A observação participante não foi abandonada completamente, mas se resumiu ao olhar, à identificação e fotografia dos lugares, e anotações sobre as crianças interagindo entre si e com o meio, além de seus comentários espontâneos. A princípio, parecia frustrante pensar a pesquisa sem escutar delas respostas para as minhas dúvidas e curiosidades, mas tão logo as entrevistas cessaram e os passeios aos lugares de costume foram se espaçando, partiu delas próprias a vontade de rememorar os lugares.

Antes de tudo, é preciso compreender que lembrar é a capacidade de evocar o que foi vivido, percebido, sentido, aprendido. Isto é, a "informação adquirida através de experiências" (IZQUIERDO, 1989, p. 89). Essa aquisição, armazenamento e recuperação, é o que entendemos como memória que, quanto ao seu conteúdo, pode ser dividida em não-declarativa, quando diz respeito aquilo que é adquirido e evocado de "maneira mais ou menos automática" (IZQUIERDO, 2013, p. 11), aos hábitos, às habilidades motoras como saber andar, segurar um objeto; e a memória declarativa, que diz respeito a lembrança propriamente dita em seu aspecto semântico (aprendizado de linguagens, conhecimentos) ou episódico (recordação de fatos, eventos genéricos ou autobiográficos).

Pesquisas desenvolvidas por Katherine Nelson $(1993)^{20}$ demonstraram que crianças de três anos de idade são capazes de recordar eventos familiares genéricos, como a ida a um restaurante favorito, atividades na escola, além de também conseguirem:

[...] lembrar de eventos recentes, dentro de certos limites, e às vezes, muito facilmente conseguem relatar episódios que consideram interessantes. Quando questionados sobre eventos rotineiros, elas simplesmente dão respostas rotineiras. Mas quando questionadas sobre eventos recentes, muitas vezes elas são capazes de responder com detalhes mesmo estando na faixa dos dois anos e meio. Pesquisas mais recentes verificaram que crianças possuem lembranças episódicas específicas que podem ser recordadas por períodos longos — até dois anos, em alguns casos - e antes da idade das primeiras memórias autobiográficas relatadas pelos adultos (NELSON, 1993, p. 9, tradução nossa $)^{21}$.

\footnotetext{
${ }^{19}$ Ao final da entrevista, já com o gravador desligado, Maria resume o que tinha achado de toda a experiência. ${ }^{20}$ Nesse trabalho, a autora utiliza como exemplo os estudos que a Dra. Judith Hudson (1990), psicóloga especialista em memórias de infância, conduziu em sua filha de dois anos de idade, na época.

21 "Young children do remember novel events, within limits, and sometimes quite readily report episodes that they find interesting. When asked about routine events, they simply give routine answers, but when asked about novel events, they are sometimes able to respond with details even when as young as $21 / 2$ years. More recent research has verified that children do have specific episodic memories and can remember them for extensive periods-sometimes as long as 2 years-prior to the age of the earliest autobiographical memories reported by adults".
} 
Para a autora, a partir do momento em que a criança consegue se expressar através de uma linguagem e a estruturar a sua memória de maneira narrativa (e nesse sentido, o meio social e cultural em que ela está inserida ocupa um importante papel para tal habilidade), é que se observa uma melhor (e mais duradoura) capacidade de retenção e de compartilhamento de memórias.

Esse entendimento de que crianças seriam capazes de se lembrarem de eventos ou fatos, principalmente quando estimuladas pelo constante diálogo com adultos, por estímulos sociais (NELSON, 1993), me ajudou a presumir que os lugares da cidade, suas impressões e histórias poderiam ser obtidas através da história oral temática - uma tipologia da história oral mais direta, objetiva, que gira em torno de um tema definido, diferente dos outros dois tipos de história oral, a história de vida e a tradição oral (MEIHY, 2002).

No entanto, apesar dessa capacidade rememorativa, logo me percebi diante de outras questões: de que forma deveria proceder a história oral com crianças tão pequenas? Será que estariam dispostas a lembrar/narrar sobre os seus lugares favoritos na cidade? Será que não se sentiriam entediados e incomodados como nas entrevistas anteriores? Pelo fato de ser a mãe das crianças, o processo seria mais fácil ou mais difícil? A ideia de utilizar a navegação no GMSV poderia ser útil de fato?

Antes é preciso diferenciar que a lembrança compartilhada, seja ela por uma criança ou por um adulto, não diz respeito à lembrança como um todo, mas "é apenas a expressão parcial entre outras tantas possíveis" (CANDAU, 2012, p. 33), é uma representação daquilo que está conservado e não a sua totalidade, e como tal, pode ser influenciado, durante a evocação, pelos mais distintos moduladores (ERRANTE, 2000), como:

Contexto de rememoração: alinhar a vontade do pesquisador à vontade das crianças em relatar as suas lembranças. Ex.: a ideia de escutar as histórias de João e Maria só pode se tornar realidade quando eles demonstraram interesse em rememorar os seus lugares favoritos da cidade, seja pedindo para voltar a visitá-los - pois assim poderiam retornar às brincadeiras, reencontrar amigos, consumir os produtos - seja pedindo para ver fotografias dos lugares na internet ou navegando pelo GMSV, pois assim poderiam contar mais acertadamente as histórias que ocorreram em pontos específicos da cidade. Sem um contexto favorável, a criança pode preferir dizer que "esqueceu", que não possui nada para relatar.

Narrativa de identidade: as crianças possuem uma imagem de si mesmas, de como querem ser vistas pelo outro e quais interesses possuem com o evento narrado. Ex.: nesse caso, existiam os papéis bem definidos de mãe e de filhos e, durante as entrevistas, 
não foram raros os momentos em que eles deixavam claro que não somente estavam lembrando-se dos lugares onde gostam de ir, dos quais lembram as características físicas e onde ocorreram algumas histórias que conseguem recordar, mas também estavam lembrando a mãe, como filhos, que aqueles eram os lugares que gostariam de voltar a frequentar em um futuro próximo por interesses particulares.

Responder a expectativas: as crianças podem encarar o evento como um jogo em que elas precisam acertar a maior quantidade de respostas. Isso pode ocorrer principalmente quando não possuem uma resposta/lembrança com relação à pergunta feita e não desejam desapontar o entrevistador. Ex.: em caso de esquecimento, elas ficavam em silêncio, mas logo tentavam "agradar" inventando alguma resposta.

Para que eles participassem das entrevistas como meus informantes, um convite diferente foi feito a cada um. Para Maria, de cinco anos, perguntei se poderia me ajudar a lembrar de alguns lugares da cidade, que a ajuda seria importante, que usaríamos um computador para ver fotos em um mapa e um gravador de voz, como os utilizados pelos jornalistas (eu sabia, por ser sua mãe, que desde que ganhara um microfone de Natal, ela gostava de brincar de entrevistar quem estivesse por perto, como uma repórter). No caso de João, por ter apenas três anos, não elaborei uma imagem muito complexa do papel a ser representado. Apenas tentei transmitir que aquela seria uma brincadeira em que ele poderia fazer duas coisas que lhes são muito caras: ver imagens de lugares conhecidos no computador e navegar pelo mapa. Mais uma vez, a minha proximidade facilitou a elaboração do convite mais apropriado também com a criança mais nova. Aliás, a ideia de utilizar mapas como evocadores de memórias surgiu devido a uma iniciativa do próprio João enquanto brincava com o pai de relembrar os passeios do dia.

De certa forma, o estilo de convite feito também determinou como cada um se comportaria, isto é, de acordo com o que eles consideravam que se esperava deles. Maria respondeu às perguntas bastante concentrada, séria, procurando colaborar e, principalmente, não errar. Quando não tinha o que relatar, ela parecia responder a primeira ideia que lhe surgia à mente e que lhe soasse uma boa resposta, como por exemplo, comentar que gostava de muitas árvores e logo em seguida responder que um campo sem árvores é bonito por ter interpretado que estaria ajudando mais se respondesse que gostava de qualquer característica da cidade. Ao contrário de João, que entendia tudo como uma brincadeira onde ele podia, inclusive, se ausentar por uns momentos para fazer outras atividades ou pegar alguns brinquedos para acompanhá-lo na diversão. 
Para os dois, que foram entrevistados isoladamente, as primeiras perguntas foram simples (nome, idade, cidade onde moram, entre outras), assim eles poderiam ir se familiarizando com a dinâmica. Durante essa primeira rodada de perguntas foi possível identificar que João utilizava o verbo "morar" para se referir aos lugares em que ele gosta de estar/ir (detalhe já observado durante os passeios). Nos dois casos, apenas quando o silêncio se tornou uma constante, que o mapa passou a ser utilizado.

O Google Maps $^{22}$ possui três visualizações disponíveis: o desenho de um mapa simplificado; a imagem de satélite como mapa, com detalhes de árvores, prédios, pavimentação; e o Street View, onde é possível navegar "dentro" do mapa, quase como se estivesse caminhando pelas ruas (Figura 16).

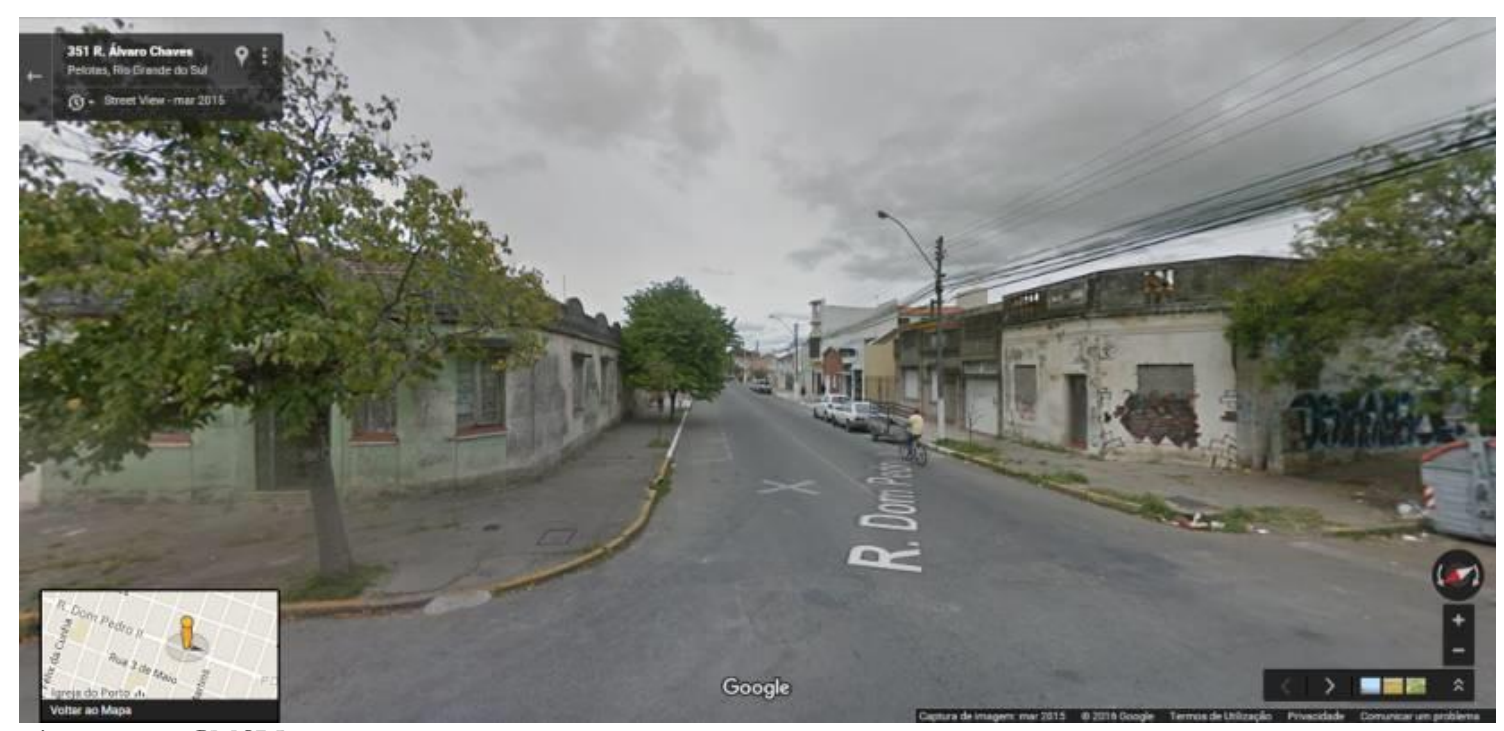

Figura $16-G M S V$

Fonte: Printscreen GMSV, mar. 2016.

A configuração escolhida como evocador de memórias foi o GMSV, pois além de disponibilizar imagens dos lugares já conhecidos, as crianças também poderiam identificar e repetir trajetos e, dessa forma, ir além das lembranças de pontos fixos, mas também demonstrar - ou não - na lembrança dos percursos feitos pela cidade.

A dinâmica utilizando o mapa funcionou nos seguintes graus:

Procurar os pontos indicados pelas crianças. Ex.: se gostariam de ver a praça, ou o shopping, procurávamos esses lugares no mapa para que, ao vê-los, as lembranças surgissem, espontaneamente ou através de perguntas sempre focadas no espaço físico dos lugares.

Procurar os pontos indicados por eles, mas posicionar o cursor nas proximidades. Ex.: ao indicar que gostariam de visitar a "Casa da Formiga", sugerir uma rua

22 Serviço gratuito desenvolvido e fornecido pela empresa Google para visualização de mapas. Pode ser acessado em: < https://maps.google.com.br/>. 
próxima, em que o prédio não pudesse ser visualizado, para que eles demonstrassem se estavam perto ou longe do lugar desejado e se saberiam informar qual direção deveríamos percorrer para chegar ao ponto desejado. Essa foi uma das dinâmicas mais interessantes de observar, porque além de saberem que estavam nas proximidades do lugar que gostariam de ver, ainda que o mesmo não estivesse à vista, eles conseguiam lembrar que direção deveriam seguir, em quais ruas deveriam entrar para chegar ao destino. $\mathrm{Na}$ maioria das vezes os caminhos propostos eram os caminhos percorridos pelo carro, e João, que normalmente gosta de "passear" pelo mapa com o pai, como uma brincadeira que complementa a sua experiência na rua, acertou mais vezes que Maria as direções a serem seguidas.

\section{Escolher um ponto aleatório no mapa para que eles tentassem lembrar o que} poderiam encontrar nas redondezas. Ex.: como possuo o conhecimento dos lugares por onde eles normalmente passeiam pela cidade, eu poderia indicar com mais certeza pontos conhecidos. Mesmo que não deixasse claro qual lugar estávamos procurando, eles conseguiam identificar pelos arredores, a partir de elementos como marcos, caminhos e limites (LYNCH, 1982), os lugares que encontrariam se fossem um pouco mais para frente ou para o lado no mapa. E durante o percurso de "andar" no mapa, eles apontavam prédios, casas, detalhes da paisagem que lhes eram familiares.

Todos os lugares lembrados com o auxílio do mapa coincidiam com os observados na pesquisa de campo. Em muitos momentos, porém, as lembranças discordavam das percepções que eles tinham dos lugares vivenciados pessoalmente, muito porque a visualização do mapa se restringia a um nível superficial de espaço e de tempo, quer dizer, não era possível entrar na praça, nem no mercado, muito menos no shopping, assim como as transformações ocorridas nos lugares no decorrer do tempo nem sempre correspondiam às registradas no GMSV. João, aliás, foi o que mais se sentiu frustrado com a impossibilidade de aprofundar suas visitas no mapa, e por vezes se sentia enganado pela sua própria imaginação ao procurar, em vão, por elementos efêmeros ou inexistentes: se, por exemplo, ele lembrava que um dia avistara um trem na rua do shopping, ele gostaria de ver no mapa um trem passando na rua do shopping, pois para ele, aquele trem lhe servia como um referencial (seria mesmo aquele a rua do shopping se aquele trem não estava ali?). Aliás, descobrir que o mapa não era uma representação fiel das suas recordações foi o que o fez desistir de participar da entrevista de lembrar as experiências vividas, para retornar ao presente dos sentidos, das brincadeiras, da ação.

\section{CONCLUSÃO}


Esse trabalho sobre a percepção da cidade por crianças, com auxílio das lembranças coletadas através da história oral possui um caráter experimental, uma vez que o número de crianças envolvidas na pesquisa se resumiu a apenas dois indivíduos, uma menina de cinco anos e um menino de três. Por outro lado, a quantidade reduzida facilitou a criação de um relacionamento de confiança e respeito que, no meu caso, era intensificado por se tratar de uma relação entre mãe e filhos.

A convivência e a familiaridade foram um facilitador para a identificação da incidência de falsas memórias, seja por causa da imaginação, para indicar os lugares que gostariam de visitar em um futuro próximo e o que planejavam ir fazer/consumir neles, seja, até mesmo, para impressionar a entrevistadora, no caso, a mãe, a quem eles queriam agradar ajudando com respostas certas. No caso de utilizar o método com outras crianças, talvez fosse necessário também entrevistar os adultos responsáveis para que, através da comparação de respostas, seja possível um entendimento maior sobre os lugares especificados e, consequentemente, uma melhor compreensão da relação entre a percepção das crianças ao interagirem com o ambiente e o momento posterior, relembrando esse mesmo ambiente.

Ficou evidente que, principalmente João se utiliza de muitos elementos marcantes (LYNCH, 1982) para entender a imagem da sua cidade. Ao navegar pelo GMSV, ele conseguia narrar a sequência em que poderíamos encontrar as torres se seguíssemos pelas ruas indicadas. Maria identifica as torres e os espaços físicos que o irmão também identifica, mas sem se prender a esse nível individual de coisas, se preocupando mais com a relação delas e com os enredos que a sua imaginação elaborava a partir dessas relações.

Também foi possível notar que, para eles, os lugares já começavam a acumular significados. No caso de Maria, a que mais colaborou durante a história oral, lhe remetendo a histórias, lembranças e sentimentos complexos; no caso de João, lhe remetendo a lugares em que consumiu ou que poderia vir a consumir algum produto/divertimento. Maria também demonstrou interesse pelos lugares de consumo, mas sem empolgação quanto aos prédios/elementos marcantes.

A maneira como eles associavam significados aos lugares, além dos detalhes observados e lembrados em determinados percursos - em se tratando apenas da navegação pelo mapa - pareciam ir um pouco além das descrições de Tuan (1983). Contudo, seria preciso observar no ambiente, preferencialmente durante o passeio a pé, se eles, de fato, poderiam indicar trajetos corretos e como lidariam com as mudanças ocorridas na paisagem (alguns dos lugares fotografados durante a pesquisa sofreram 
alterações nos últimos meses; uma loja de brinquedos, por exemplo, lembrada por Maria durante o "passeio" pelo mapa, uma de suas referências espaciais, já não existe mais).

Fora essas observações, que ainda podem ser conduzidas, acredito que possa ser relevante retornar a ouvir essas crianças no futuro, já adultas, para tentar identificar de que maneira os lugares citados como significativos hoje lhes retornam à memória, e que sentimentos lhes provocam. Talvez só seja complexo aferir o quanto as futuras lembranças também serão influenciadas pela participação nessas entrevistas. Hoje, não existe uma resposta, mas talvez uma boa relação com a cidade possa brotar em pessoas que, desde muito cedo, são convidadas a enxergar e pensar o espaço ao redor, tendo suas percepções, opiniões e lembranças sobre a cidade estimuladas, escutadas e valorizadas.

\section{REFERÊNCIAS}

CÂMARA MUNICIPAL DE PELOTAS. Em audiência, moradores e escola aprovam prédio da Câmara na Praça Palestina. 2015. Disponível em: $<$ http://www.camarapel.rs.gov.br/imprensa/em-audiencia-moradores-e-escola-aprovampredio-da-camara-na-praca-palestina/>. Acesso em: 25 jan. 2016.

CANDAU, J. Memória e Identidade. São Paulo: Contexto, 2012.

COLLOT, M. Pontos de vista sobre a percepção das paisagens. Boletim de Geografia Teorética, Rio Claro, v. 20, n. 39, p. 21-32, jan. 1990.

ERRANTE, A. Mas afinal, a memória é de quem? Histórias orais e modos de lembrar e contar. Revista História da Educação, Pelotas, v. 4, n. 8, p. 141-174, set. 2000. Disponível em: < http://www.seer.ufrgs.br/asphe/article/viewFile/30143/pdf>. Acesso em: 01 nov. 2016.

HUDSON, J. A. The emergence of autobiographic memory in mother-child conversation. In: FIVUSH, R.; HUDSON, J. A. (Org.). Knowing and remembering in young children. New York: Cambridge University Press, 1990. p. 166-196.

IZQUIERDO, I. A. Memórias. Revista Estudos Históricos. São Paulo, v. 3, n. 6, p. 89112, mai./ago. 1989. Disponível em: $<$ http://www.scielo.br/scielo.php?script=sci arttext\&pid=S0103-40141989000200006 $>$. Acesso em: 01 nov. 2016.

; MYSKIW, J. C.; BENETTI, F.; FURINI, C. R. G. Memória: tipos e mecanismos - achados recentes. Revista USP, São Paulo, n. 98, p. 9-16, jun./ago. 2013. Disponível em: <http://www.revistas.usp.br/revusp/article/view/69221/71685>. Acesso em: 01 nov. 2016.

JOÃO. João: Entrevista I. [out. 2015]. Entrevistador: Karla Nazareth-Tissot. Pelotas, 2015. 1 arquivo .mp3 (47 min.). 
LUKASHOK A. K.; LYNCH, K. Some Childhood Memories of the City. Journal of the American Institute of Planners, Chicago, v. 22, n. 3, p. 142-152, 1956.

LYNCH, K. A Imagem da Cidade. Martins Fontes: São Paulo, 1982.

MARIA. Maria: Entrevista I. [out. 2015]. Entrevistador: Karla Nazareth-Tissot. Pelotas, 2015. 1 arquivo .mp3 (51 min.).

MEIHY, J.C.S.B. Manual de história oral. São Paulo: Loyola, 2002.

NELSON, K. The psychological and social origins of autobiographical memory. Psychological Science, Califórnia, v. 4. n. 1. p. 7-14, jan. 1993. Disponível em: $<$ http://journals.sagepub.com/doi/pdf/10.1111/j.1467-9280.1993.tb00548.x $>$. Acesso em: 01 nov. 2016.

OLIVEIRA, R. C. O Trabalho do Antropólogo: olhar, ouvir, escrever. In: $\mathbf{O}$ trabalho do antropólogo. 2. ed. Brasília/São Paulo: Paralelo Quinze/Editora da UNESP, 2000. p. 17-35.

ROCHA, S. A. Geografia humanista: história, conceitos e o uso da paisagem percebida como perspectiva de estudo. Ra'e Ga - O Espaço Geográfico em Análise, Curitiba, v. 13, p. 19-27, 2007. Disponível em: < http://revistas.ufpr.br/raega/article/view/7670>. Acesso em: 01 nov. 2016.

SEBBA, R. The landscapes of childhood: the reflection of childhood's environment in adult memories and in children's attitudes. Environment and Behavior, Califórnia, v. 23, n. 4, p. 395-422, jul. 1991.

TUAN, Y. F. Topofilia: um estudo da percepção, atitudes e valores do meio ambiente. São Paulo: DIFEL, 1980.

Espaço, Lugar e a Criança. In: Espaço e Lugar: a perspectiva da experiência. São Paulo: DIFEL, 1983. p. 22-38.

Recebido para avaliação em 19/05/2016

Aceito para publicação em 19/10/2016 